\title{
GOVERNABILIDADE, INFORMAÇÃO E FISCALIZAÇÃO POLÍTICA
}

Duas décadas após a chamada "vitória" da democracia liberal, materializada na célebre frase de Fukuyama "O fim da história", constata-se que o estágio democrático das novas democracias está longe de estar consolidado. Persistem problemas, sobretudo de caráter social, que constrangem o pleno desenvolvimento democrático, principalmente dos países emergentes.

Tal situação tem plasmado o que para muitos é definido como uma "zona cinzenta", ocupada por regimes que mostram aspectos autocráticos e de democracia liberal e identificados como regimes híbridos. Nessas circunstâncias, a despeito do razoável funcionamento das instituições encarregadas de regular o comportamento social, a cultura política e a relação Estado-sociedade continuam a evidenciar fragilidades comprometedoras dos princípios republicanos.

O senso de anomia dos cidadãos nas sociedades emergentes, considerado com a incerteza sobre o futuro e a crescente desconfiança nas instituições e gestores públicos, gera um cenário típico para a reprodução de vícios e práticas políticas tradicionais que inibem o pleno desenvolvimento democrático.

Foi pensando nesses questionamentos que este dossiê foi desenvolvido. Os temas examinados proporcionam uma compreensão rica a respeito da governabilidade, pensada além da dimensão da engenharia institucional; a corrupção; o papel das instituições formais na fiscalização das agências reguladoras; a qualidade da democracia e as novas formas de informação na política.

No primeiro artigo "Gobernabilidad: una aproximación conceptual desde la perspectiva de la gubernamentalidad", Martín Carné examina a pertinência e as potencialidades que a perspectiva da gubernamentalidad pode oferecer à categoria "governabilidade" para além das abordagens de corte institucionalista que predominam na Ciência Política da América Latina. Nesse sentido a perspectiva da governamentalidade, segundo o autor, oferece ferramentas úteis para tratar a governabilidade de uma ordem política.

No segundo artigo "O papel do Congresso Nacional e do Tribunal de Contas da União na fiscalização das agências reguladoras: abdicação ou delegação de poderes?", Monique Menezes, examina o processo de accountability das instituições regulatórias brasileiras, mais especificamente, no controle exercido pelo Congresso Nacional Brasileiro, através do Tribunal de Contas da União.

O terceiro artigo "Corrupção e padrões de ineficiência nas gestões municipais detectados por corte de conta estadual", de autoria de Clóvis Alberto Vieira de Melo e José Wilas Pereira, busca identificar o que motiva reprovações de prestações de contas municipais por parte do Tribunal de Contas Estadual. Os autores testaram e confirmaram duas hipóteses, quais 
sejam, a existência de casos de corrupção e impropriedade administrativa, esta última envolvendo casos de negligência, imprudência ou imperícia.

No quarto artigo "Dimensões teóricas e práticas da qualidade da Democracia", de Maria Salete Souza de Amorim e Rodrigo Rodrigues Dias, os autores situam o Brasil no atual debate sobre a qualidade da democracia, problematizando o tipo de apoio e satisfação com a democracia e confiança nas instituições políticas. O estudo mostra que, do ponto de vista da institucionalidade política, a qualidade da democracia no Brasil tem sido avaliada positivamente, mas do ponto de vista dos seus conteúdos e da efetividade de seus resultados, a democracia ainda não alcançou patamares qualitativos mais substantivos.

No quinto artigo intitulado "Lei de Acesso à Informação: notas e um breve exemplo", de Marcelo Gruman, são analisados os principais pontos da Lei n. 12.527, conhecida como Lei de Acesso à Informação, relacionando-os a conceitos como democracia, transparência, controle social e gestão compartilhada. O autor conclui que a consolidação da democracia no Brasil está associada a uma administração pública regida pelo princípio da eficiência nos gastos públicos a partir de políticas públicas elaboradas segundo as demandas da sociedade, e que a cultura do acesso permite cada vez mais a participação da sociedade na avaliação das ações do Estado, inclusive a proposição de mudanças de rumo.

No último texto do dossiê "Quem pode falar no Facebook? O 'autocontrole' em um grupo sobre o plebiscito acerca da divisão do Estado do Pará", de Ricardo Fabrino Mendonça e Danila Cal, é discutida a legitimação ou contestação do direito à fala em um grupo do Facebook, criado por ocasião do plebiscito sobre a divisão do Pará. Os autores examinam a questão de homofilia, bastante trabalhada na literatura sobre internet e política. Também problematizam a literatura atual sobre representação política, explorando ambiguidades da accountability discursiva.

O dossiê ainda conta com dois artigos livres sendo um sobre as Diretas Já e um texto sobre egressos do sistema penitenciário, bem como três resenhas. 